ROCZNIKI TEOLOGICZNE

Tom LXVII, zeszyt $1-2020$

DOI: http://dx.doi.org/10.18290/rt20671-4

\title{
H5 MODEL CONCERNING REFUGEE FAMILY TRAUMA AND RECOVERY AND ITS APPLICATION IN SOCIAL WORK PRACTICE - TOWARDS AN IMPROVED REFUGEE FAMILY ASSISTANCE. THEORETICAL AND PRACTICAL CONSIDERATIONS
}

\begin{abstract}
The authors explore the complexities of human dignity, analyze human dignity as a concept and its position within the framework of today's social work practices. In this regard, the authors ponder upon diverse understanding of human dignity, including human dignity as a socio-legal value and its importance to social work in general and to other principal values relevant for social work. They examine the evolution of social work approaches towards human dignity while focusing on social work related international organizations and their national members' and partners' work to promote and uphold human dignity in delivery processes of social services.
\end{abstract}

Key words: trauma-informed care; refugee; refugee family; social work; social work practice; therapeutic social work.

\section{INTRODUCTION}

The United Nations assess that there are 25,4 million refugees worldwide out of which a half are under the age of 18 years old. Each day 44,400 persons leave their homes due to armed conflicts, humanitarian and natural dis-

Prof. UPJPII LEON SzOT - the Social Work Institute, Pontifical University of John Paul II; address for correspondence: 3 Bernardynska St., 31-060 Cracow; e-mail: leon.szot@upjp2.edu.pl

Rev. Prof. MirosŁaw Kalinowski - Head of the Social, Palliative and Hospice Care Department, Director of the Institute of Family Sciences and Social Work at the John Paul II Catholic University of Lublin, address for correspondence: 7 Radziszewski St., 20-039 Lublin; e-mail: miroslaw. kalinowski@kul.pl 
asters. ${ }^{1}$ A large number of family refugees experience brutality and violence in countries of their origin from which they are forced to flee unexpectedly. International surveys assess psychic traumatic disorders among refugees to be as frequent as 30-70\%. The Post Traumatic Stress Disorder (PTSD) among refugee torture victims are assumed to occur in $80-90 \%$ clinical cases. ${ }^{2}$ The trauma which has built upon this socio-mental condition requires a complex recovery treatment mechanism. There are few innovative approaches towards the issue that have been developed over last years; however none has yet become a worldwide legal mechanism to be used by social workers worldwide. ${ }^{3}$

\section{REVIEW OF SOCIO-MEDICAL MODELS AIMING AT IMPROVED TRAUMATIZED REFUGEE FAMILY ASSISTANCE}

Social work practitioners point at several models which might turn useful to improve refugee family assistance. The Refugee Health Screener 15 (RHS 15) model is a brief - as of 2011 mandatory tool used in King CountyWashington - developed by M. Hollifield in 2002 to identify anxiety, depression and PTSD among refugees. An assessment questionnaire is to enable an early screening of refugees' socio-mental condition. The RHS 15 was developed on the frame of complex methodology involving discriminant analysis, naïve Bayesian analysis and chi-square for each item of diagnostic proxy. In total, 75 items were selected to support the screening as most representative, and a distressing thermometer was included to support diagnostic proxies. The Questionnaire approximately takes 10 minutes to be filled in depending on the interaction of a social worker with a refugee and includes 15 inquiries about types and periods of physical and mental symptoms experienced by refugees, their general feeling about the life situations they have been through and the distressing thermometer. The questionnaire has the following scoring explanation; screening is positive if the score of positive answers to items $1-14$ is 12 or less than 12 and the distressing thermometer

\footnotetext{
${ }^{1}$ United Nations, Figures at a Glance, Statistical Yearbooks, October 2018, https://www. unhcr.org/figures-at-a-glance.html (10.03.2018).

${ }^{2}$ M. BrandmeIER, J. Kruse, Trauma und Asyl in Flüchtchlingsrecht in Theorie and Praxis: 5 Jahre Refugee Law Clinic an der Justus-Liebig-Universität Giessen, in P. TIEDEMANN, J. GIESEKING, Flüchtlingsrecht in Theorie und Praxis (Baden Baden, 2014), 125-141.

${ }^{3}$ K. JACKSON, “Treating Trauma in American Refugees," Social Work Today (2016), 16,4: 10.
} 
equals or is less than 5 in the scale of 10 points (from no distress to extreme distress - "things are good" to "I feel as bad as I ever have").

Recently, in 2017, the RHS 15 approach was tested in the research conducted by Stingl et al to detect traumatic disorders in a refugee sample in Germany, also as an attempt to incite the EU member states to use this model within the EU zone. The refugee sample included 126 refugees who resided in an initial reception center and 115 who were accommodated in long-term communal buildings. The researchers indicated a good practical feasibility of the model and stressed the importance of political, legal and medical factors which were crucial for the interpretation of the results. It appeared that $2 / 3$ of refugee sample had a positive screening result which required further diagnosis. ${ }^{5}$

The 1994 Culturagram by E.P. Congress, revised in 2002 and 2009 by the researcher is a more complex model - a pictographic representation of a family in 10 areas of assessment for potential use by social workers. The model areas embrace the following: inquiry into reasons of relocation; legal status; time in community; languages spoken at home and in community; health beliefs; impact of trauma and crisis events; contact with cultural and religious institutions; holidays; food and clothing beliefs; oppression, discrimination, bias and racism; values about education and work; values about family - structure, myths, power and rules. ${ }^{6}$ The current social practice in the United States have displayed that the use of the culturagram proved particularly effective in the intervention practice with refugee families, i.e. in engaging families in a non-threatening way. The element of culture in the model remains focally multidimensional, receives positive opinions and requires further assessments by social work practitioners. ${ }^{7}$

\footnotetext{
${ }^{4}$ Pathways to Wellness, Refugee Health Screener 15 (RHS 15) (Washington, 2011), 1-21. The Pathway to Wellness is a partnership project of Lutheran Community Services NW, Asian Counsel and Referral Services, Public Health Seattle and King County, dr Michael Hollifield of the Pacific Institute for Research and Evaluation. The Project is funded by the Robert Wood Johnson Foundation, the Bill and Melinda Gates Foundation, United Way of King County, M.J. Murdock Trust, The Medina Foundation, The Seattle Foundation and Boeing Employees Community Fund. Pathways to Wellness, Refugee Health Screener 15 (RHS 15) (Washington, 2011), 21.

${ }^{5}$ M. Stingl, M. KnipPer, B. Hetzger, J. Richards, B. YAZGAn, B. Gallhofer, B. HANEwald, Assessing the Special Need for Protection of Vulnerable Refugees: Testing the Applicability of a Screening Method (RHS 15) to Detect Traumatic Disorders in a Refugee Sample in Germany in Ethnicity \& Health 2017, https://doi.org/10.1080/13557858.2017.1379598 (1.03.2019).

${ }^{6}$ E.P. Congress, "The Culturagram," in A. RoberTs, Social Work Desk Reference (New York-Oxford, 2008), 969-973.

${ }^{7}$ E.P. Congress, "The Culturagram," in K. CorCoran, A.R. Roberts, Social Worker's Desk Reference (New York, 2015), 1017.
} 
The next model formulated by M. Potocky and K. Guskovict in $2016-$ the Motivational Interviewing for Refugee Adaptation, Coping and Life Empowerment Project (Miracle) - is an evidence-based (MI) ${ }^{8}$ and person-centered practice approach which aims at helping refugees and service providers resolve and explore ambivalences about their behavioral changes. With that regard, the Helpful Responses to Refugees Questionnaire (HRRQ ${ }^{9}$ ) was prepared to measure empathic responsiveness among service providers of the U.S. resettlement programs who worked with refugees, including torture survivors. In the course of the study 102 questionnaires have been completed. Sample characteristics embraced type of education and degree, length of work experience with refugees, type of held position, questions about training in MI and active listening. The study authors concluded that the HRRQ might be a useful tool to assess and/or supervise service providers' skills, and screen potential staff members. It might also serve as a pretest-posttest to evaluate the impact of training which staff members have undergone in MI. ${ }^{10}$ The Project Miracle received wide attention at the United Nations. ${ }^{11}$

The Imagery Rescripting Technique is another approach which has been identified by M. Naseh (Ahmadinejad). The author conducted a review of PTSD literature 2001-2016 which led her to show that trauma survivors imagined his/her traumatic event and subsequently imagined fortunate circumstances which lead to a more positive outcome of the event. In addition, M. Ahmadinejad had proposed the use of the Narrative Exposure Therapy $(\mathrm{NET})^{12}$ among refugee communities to facilitate them a reflection upon

${ }^{8}$ The MI has been applied in many areas: health and social work and was initially developed by R. Miller in 1983. Empathy is the core skill of the interviewing technique and is assessed to result in better client management. W.R. MiLLER, S. RoLLNICK, "Ten Things that Motivational Interviewing is not," Behavioural and Cognitive Psychotherapy (2009), 37, 2: 129-140.

9 The HRRQ was based on the Helpful Responses Questionnaire (HRQ) which is commonly used in the MI practices and was crafted to measure reflective listening. Empathy, by large, has been considered to be its main part. The questionnaire consists of six scenarios to engage interlocutors in the conversation about health, addition and social settings. W.R. MiLLER, C.E. YAHNE, T.B. MOYERS, J. Martinez, M. Pirritano, "A randomized trial of methods to help clinicians learn motivational interviewing," in Journal of Consulting and Clinical Psychology (2004), 72: 1050-1062.

${ }^{10}$ M. Ротоску, K.L. Guskovict, "Enhancing Empathy among Humanitarian Workers through Project Miracle: Development and Initial Validation of the Helpful Responses to Refugee Questionnaire," Torture (2016), 26,3: 46-59.

${ }^{11}$ OXFoRd UnIVERsity PRESS BLOG, The UN Summit for Refugees and migrants: A Global Response includes Empowering One refugee at a Time, https://blog.oup.com/2016/09/un-summitrefugees-migrants-mi/ (2.09.2018).

${ }^{12}$ Narrative Exposure Therapy - treatment for trauma-spectrum disorders for survivors of complex trauma situations. The patient, with the assistance of the therapist, reconstructs a chronological narrative of his/her life stories with a focus on trauma. The therapy was developed by M. SCHAUER, 
their negative experience and help them diffuse emotional sturdiness and trauma. $^{13}$

The Integrative Approach Theory for work with refugees is particularly crafted for social work practitioners who work with refugee groups and refugee families. A. Hilado and M. Lundy have proposed the use of integrative theory in transnational social practice work very recently. The integrative model provides methods to address trauma as briefly as possible with more time to narrate his or her personal experience after which they have to be thoroughly examined. They are applied to specific needs, modified and adapted depending on how the intervention is being processed. The theory assumes that a mutually respectful, culturally sensitive, collaborative relationship is established between a client and the group. The model is based on cultural awareness and the idea of collaboration which should build into the narrative. It does not have a singular theoretical foundation and guides therapy and engagement while taking into account pre- and post- migration stressors which directly impact refugees' mental and social condition. The model acknowledges the possibility to use a questionnaire, including RHS 15 ; however the idea of narration itself precedes the importance of the questionnaire. ${ }^{14}$

In turn, the $\mathrm{H} 5$ model considerably differs in terms of scientific perspective undertaken by the researcher - its founder - R.F. Mollica. The model was published in its initial form in 2014. It is an-evidence based holistic instrument addressing major sources of risks and vulnerabilities affecting highly traumatized communities, particularly refugee families residing in camps. The model deals with the physical and mental health aspects of trauma, their relationship, the potentials for trauma and the need for a comprehensive refugee care model. The H5 examines five overlapping dimensions which are considered basically essential to trauma recovery by highlighting studies' results conducted among refugee populations. The model is new due to its implementing culture recommendations and evidence-based policies identified as crucial to tackle trauma in refugee communities. The model received widespread acclaim, attention from mental health practitioners and mainstream media for it has become the first model to address from a theoretical perspective the major source of vulnerability and risk affecting traumatized

F. NeUER, T. ElBERT, Narrative Exposure Therapy: A Short Term Treatment for Traumatic Stress Disorders (Cambridge, 2002), 37-74.

${ }^{13}$ K. JACKSON, "Treating Trauma."

${ }^{14}$ A. Hilado, M. Lundy, Models for Practice with Refugees and Immigrants, Collaboration, Cultural Awareness and Integrative Theory (Los Angelos-London, 2018), 82-95. 
refugee communities as well as to connect intertwiningly two aspects: cultural and psychosocial. ${ }^{15}$

\section{THE NEW H5 MODEL FOR TRAUMA AND RECOVERY - MAIN CHARACTERISTICS}

The model's full review and characteristics by R.F Mollica and coauthors: D.R. Brooks, S. Ekblad, L. McDonald were issued by Springer Publishing. ${ }^{16}$ The five overlapping dimensions and core elements of the Model central to the Trauma Story are: 1) Human Rights; 2) Humiliation; 3) Healing (self-care); 4) Health promotion; and 5) Habitat and Housing. Trauma stories are accounted for stories which are told by survivor patients of painful and distressing social and personal events. Sharing these stories has dual purpose - to heal the survivor as well as to guide and teach the listener, i.e. mental health practitioner, social work practitioner, society.

The Trauma Story consists of four elements: Brutal Facts which might be collected, documented to charge perpetrators of crimes, including against humanity and brutality; Cultural Meaning of Trauma which embrace survivor's sociocultural history, customs, values and his/her spiritual life; Enlightened View of the World or posttraumatic growth which allows for a divorce from distressful and tragic events; and Listener - Storyteller Relationship which require listener's patience and sensitivity, his/her will to become part of the story, ideally listener to be the student and the storyteller to be the teacher, however it should be the listener to apply lessons of survival and healing. The stories must be presented by survivors in their own way individually or in groups. ${ }^{17}$

Authors of the H5 Model revoke that violations of human rights partake of what is the refugee's definition. Someone becomes a refugee if he or she is deprived of personal safety and security and is forced to flee his/her homeland. All refugees might experience violence and all these should have the right to report atrocities they have suffered from and upon which their trauma was built. Violence is not a term only reserved for crimes against humanity; it might be experienced in time of peace, not only war. On many

\footnotetext{
${ }^{15}$ R.F. MollicA, The new H5 model, Trauma and Recovery (Harvard, 2014), 3.

${ }^{16}$ R.F. Mollica, D.R. Brooks, S. Ekblad, L. McDonald, "The H5 New Model of Refugee Trauma and Recovery," in J. Lindert, I. LeVAV (eds.), Violence and Mental Health, Its Manifold Faces (New York-London, 2015), 341-378.

${ }^{17}$ R.F. MolliCA, The new H5 model, Trauma and Recovery, 3-7.
} 
occasions, lack of access or even denial to refugees the access to culturally effective health lead to extreme human suffering and further sense of loss of dignity or death. Stigma of social prejudice and waiting, at times, for many years to charge violence's perpetrators deprive traumatized refugees of basic access to human rights.

Humiliation is an important element of the model, which so far has been underestimated in other models and researches performed about the issue of trauma treatment from psycho-social perspectives. Hereby, humiliation is closely linked with feelings of embarrassment, depreciation, disgrace and shame often hidden by other powerful emotions. Violence survivors have undergone acts of e.g. rape through which they were made worthless and extremely weak, deserving pain vis-à-vis its perpetrators and the surrounding brutality of the place they were often brought to, in this sense humiliation leads to a loss of self-respect and self-efficacy, destruction of social order known before the brutal act. The Models' authors stress, that often a state of humiliation is re-created in camps due to a fact that refugees cannot live normally: go to work, make money, produce food or go to school. ${ }^{18}$

Self-healing, another core element of the Model is acknowledged in fact as the human organism's natural responses to psychological and social illness and injury. Similarly to healing wounds inflicted by physical damage, emotional damages' wounds also undergo healing processes. After the violent act occurred, a self-healing is activated to the psycho-social self. Telling stories about facts and dreams play important roles in the healing processes. Self- healing occurs in the situation when the mind is able to and has the will to build and identify a new meaning out of experienced violence. Social behaviors which the survivor is part of or witness such as work, spirituality, altruism, sense of humor, physical exercise and social support, friendship might enhance processes which reduce negativity of experienced violence and stress as well as might enable a return to normalcy. ${ }^{19}$

Health-promotion, according to the authors' model also plays a significant role in trauma recovery. The researchers proved that the connection between trauma and poor physical health among refugees itself is a must for a health promotion in this group as in many instances; trauma may generate limited or lack interest in a healthy lifestyle and favor bad habits such as drug and smoke abuse and generally might lead to an impaired lifestyle. The last core element - the Habitat connotes the total living environment and/or

\footnotetext{
18 Ibidem.

${ }^{19}$ Ibidem.
} 
surroundings were refugees reside which should be as natural and friendly as possible. The authors stress that tents in a refugee camps, which are often plagued by poverty, gender-based violence and illness, are not such a habitat for refugees and that the international humanitarian community does not understand that traumatized refugees need to enter a healing trauma-free environment rather than an in-depth trauma environment. The insertion of this core element into the model proves that there is - yet to be more researched, jointly, by humanitarian, social work and academia - a relationship between mental illness, health problems, lack of privacy, crowding and violence.

The H5 model includes specific recommendations to further improve refugee community care: 1) all human rights violations, e.g. also in the camps, should be addressed, documented and monitored as fast and effectively as possible; 2) refugee camp policies should promote and expedite self-healing, self-sufficiency and independence; 3) all refugees should be assessed to determine their need for self-healing and should be given a chance to take part in the trauma recovery programs; 4) social and aid workers should implement a program for health promotion; and 5) refugees should participate in designing, constructing and managing of their accommodations and living environment. $^{20}$

\section{INSIGHTS OF THE H5 MODEL FOR TRAUMA RECOVERY - HARVARD TRAUMA QUESTIONNAIRE AND H5 MODEL SCALE}

The H5 Model resorts, in its healing processes, to bio-psycho-sociospiritual realms of the patient. It offers a sociological approach, which integrate into one model two issues- addressing health condition of traumatized refugees as well as tackling negativity and brutality of their experienced relations with others, i.e. hereby perpetrators, broken social order - all being healed and restored at the same time. In order to document brutal acts and initiate the H5 model approach, the founder of the Model and his research group tested numerous refugee populations for 30 years both in camps and resettled scenarios around the world reaching the number $\mathrm{N}=10,000 .{ }^{21}$ With that purpose, the researcher used the Harvard Trauma Questionnaire (HTQ) - the HTQ is a checklist developed in 1993 by the H5 founder and researcher's groups working in the Harvard Program for Refugee Trauma which has

\footnotetext{
${ }^{20}$ Ibidem.

${ }^{21}$ Ibidem.
} 
been operational up to this day. The Questionnaire enquires about variety of trauma events, assessed its symptoms and is frequently revised. ${ }^{22}$

At present, there are six versions of the Questionnaire and four manuals: in Laotian, Vietnamese, Cambodian, Japanese, Indochinese, Croatian and for Bosnian refugee populations. In some versions, there were up to 82 listed traumatic events which were further addressed by relevant United Nations agencies and national authorities. The Questionnaire has since been revised five times so that this screening instrument takes into account up-to-date progress in clinical research on PTSD and other trauma related research ${ }^{23}$ as well as broader socio-medical and politico-social aspects of today's world. The revision included mapping, translation into multiple languages and comprehension amidst groups with low literacy and expert consultations. ${ }^{24}$

For instance, the Cambodian HTQ-Revised Version contains five parts and an appendix. The first part includes 41 questions with yes/no answers about trauma events, the second part - is to provide a personal description of the traumatized refugee, third part - five complex questions with yes/no answers about a head injury, the fourth part -40 questions with not at all/a little/quite a bit/extremely answers on trauma symptoms, the fifth part is the scoring for the part four and the appendix - 28 questions with answers yes/no about the torture history. The refugee who are scored on DSM (Diagnostic and Statistical Manual of Mental Disorders) -IV and/or total more than 2.5 are considered to suffer from PTSD. The Questionnaire should be filled by a trained professional - clinician and should include a psychiatric diagnosis. The traumatized refugee is free not to answer to questions which could be upsetting or awkward, however should be encouraged sensitively to answer the questions. ${ }^{25}$

\footnotetext{
${ }^{22}$ R.F. Mollica, P. Bollini, Y. CASPI, T. Truong, "Harvard Trauma Questionnaire; Validating a Cross-Cultural Instrument for Measuring torture, Trauma, and Posttraumatic Stress Disorder in Refugees," Journal of Nervous \& Mental Disease (1994), 180, 2: 107-111.

${ }^{23}$ HRPT CAMBridge, Harvard Program in Refugee Trauma, Harvard Trauma Questionnaire, http://hprt-cambridge.org/screening/harvard-trauma-questionnaire/ (3.01.2019).

${ }^{24}$ S.M. BerThOld, R.F. MOllica, D. Silove, A. KuOweI, T.J. LAVelle, J. Lindert, The HTQ-5 - Revision of the Harvard Trauma Questionnaire for Measuring Torture, Trauma and DSM-5 PTSD symptoms in refugee populations, in European Journal of Public Health, 14 December 2018, https://doi.org/10.1093/eurpub/cky256 (3.03.2019).

${ }^{25}$ Heal Torture - National Capacity Building Project of the center for Victims of Torture, Harvard Trauma Questionnaire and Hopkins System Checklist -25, https://healtorture.org/sites/healtorture. org/files/HTQ-R\%20and\%20HSCL-25\%20English\%20translation\%20of\%20Cambodian\%20version \%20with\%20Torture\%20History.pdf (4.04.2019).
} 
A culturally valid H5 model scale with psychometric properties was initially presented by R.F Mollica and his research group in 2014. Trained professionals - clinicians and therapists can therefore theoretically and in practice rate traumatized refugees' and family refugees' responses. The scale includes 5 core elements of the H5 Model. The first two - human rights violation and state of humiliation can be scored by the traumatized refugees in the form of "none" - 1/"minor" - 2/"moderate" - 3/"severe" - 4 answers. The core element three, four and five - healing activities (self): work, altruism, spirituality; health promotion; habitat/housing might be scored by the refugee with: "very good"/"adequate"/"poor"/"totally inadequate" answers. The scale is to be informative, particularly in the case of scores 3 or 4 . The scale is to guide further treatment approach for the traumatized refugees. ${ }^{26}$

\section{THE POTENTIAL USE OF THE NEW H5 MODEL IS TRAUMA-INFORMED CARE AND THERAPEUTIC SOCIAL WORK PRACTICE WITH REFUGEE FAMILIES}

The therapeutic social work started to dynamically evolve since 2000 . J. Sudbary, a key researcher in that domain, expedited the feature of relationship and emotion between the social worker and a person to which social support was delivered and/or was to be delivered to become central to reach effective therapeutic social work outcomes ${ }^{27}$. At present, the traumainformed care/and therapeutic social work is deeply rooted in the social work practice and in most countries, including the European Union - therapeutic social worker is a common profession in social aid agencies.

Trauma-informed care is designed to provide services to traumatized clients, including family refugees. It is acknowledged that trauma-informed care should incorporate "empowerment," "choice," "collaboration," "safety" and "trust" as well as should be integrated into the existing models of evidence-based services which are delivered to the traumatized clients. ${ }^{28}$ These care principles allow social workers to identify early symptoms of maladap-

\footnotetext{
${ }^{26}$ R.F. Mollica, D.R. Brooks, S. Ekblad, L. McDonald, The H5 New Model of Refugee Trauma and Recovery, 363-378.

${ }^{27}$ J. SUDBURY, "Key features of therapeutic social work: The use of relationship," Journal of Social Work Practice (2002), 16, 2: 142-162.

${ }^{28}$ D.E. Elliott, P. BJelajac, R.D. Fallot, L.S. Markoff, "Trauma-Informed or trauma-denied. Principles and Implementation of Trauma Informed Services for Women," Journal of Community Psychology (2005), 33, 4: 461-477.
} 
tive coping and the scope of trauma impact on psychosocial functioning in every daily life of the traumatized. ${ }^{29}$ Ensuring "safety" i.e. safe environments in its psycho-physical sense for the healing to be initiated is key core principle of the trauma-informed care. Subsequently, "trust" between therapeutic social worker and his/her client may be established once a traumatized client basic needs for acceptance, respect and safety are understood ${ }^{30}$ In turn, "choice" is to embolden traumatized client decision making and boost his or her sense of control over a chosen time of his or her recovery. "Collaboration" then should offer an honest alliance and relationship in healing ${ }^{31}$ and "empowerment" of the traumatized person is to occur with a strength-based approach which should restructure trauma symptoms as adaptation while displaying resilience instead of pathology. ${ }^{32}$

Trauma-informed care/therapeutic social workers should offer compassion; incite honor self-determination which should grow in their clients; and avoid any over-pathologizing comportment. ${ }^{33}$ Trauma-informed care social workers have to consider numerous factors before they would be able to analyze thoroughly the family refugee situation; potential destructive effects of child maltreatment, family chaotic environment, feelings of being oppressed and impoverished. For instance, children might suffer inconsistent parenting patterns which could impair development of secure attachments to caretakers and lead to lack of good role models for healthy interpersonal functioning. ${ }^{34}$ They might have been abused, their parents alike, which can lead to mental disorders and self-regulation difficulties. ${ }^{35}$

A therapeutic social work intervention lacked for a long time interconnectedness between a simple social work intervention, which has been mostly oriented towards livelihood community issues, relationships within and access to basic needs, and an element of spirituality and spirituality empowerment as it has been in the case in Eastern approaches to social work. With

\footnotetext{
${ }^{29}$ J.S. LeVEnson, “Trauma-Informed Social Work Practice," Social Work (2017), 62, 2: 1-9.

${ }^{30}$ D.E. Elliott, P. BJelajac, R.D. Fallot, L.S. MarkofF, “Trauma-Informed or trauma-denied," 476-478.

${ }^{31}$ R.D. Fallot, M. Harris, "Creating Cultures of Trauma-Informed Care (CCTIC), A Self-Assessment and Planning Protocol," Community Connections, April 2009, 1-19.

32 J.S. LeVEnson, “Trauma-Informed Social Work Practice,” Social Work (2017), 62, 2: 1-9.

${ }^{33}$ Ibidem.

${ }^{34}$ E.A. CARLSon, L.A. SRoufe, "Contribution of Attachment Theory to Developmental Psychopathology," in D. CichHetTi, D.J. Cohen (eds.), Developmental Psychopathology, Vol I. Theory and Methods (Oxford, 2014), 581-617.

${ }^{35}$ M. Jovev, H.J. JaCKSON, "Early Maladaptive Schemas in Personality Disordered Individuals," Journal of Personality Disorders (2004), 18, 5: 467-486.
} 
that regard, the Ecological Integrative Body-Mind-Spirit (IBMS) Social Work has been widely researched and developed by M.Y. Lee, S. Ng, P.P. Leung and C.L. Chan. The IBMS research work gained momentum in 2008 and other researchers assessed the IBMS paradigm as promising in therapeutic social work approaches towards work with conflict-induced populations, also refugees. ${ }^{36}$

According to the IBMS social work interpretation, ecological system of any person, including any traumatized refugee, called HEALTH, i.e. Healing Partnerships, Empathy, Advocacy, Lively Hood, Trauma-Informed care, Human Rights lies in the center of living circumstances. Around the ecological system, there are interconnected elements of Body, Mind, Spirit and Environment. The Body element comprises sports and hiking; walking and running; arts, music and singing; deep breathing and yoga; auriculotherapy and energy medicine; tai-chi, qi-gong. The Mind element consists of psychoeducation; expressive journaling; self-awareness and mindfulness; cognitive behavioral modification; meaning making; stress \& harm reduction. The Spirit element embraces love; acceptance; faith \& higher power, gratitude \& hope; rituals \& mantras; forgiveness; worldview; belief system. The environment element is as important as others, it is translated into the social support, altruism \& meaningful activity; faith based, health, legal, humanitarian service; education; knowledge \& skills building.$^{37}$ The IBMS researchers recognized the importance of the H5 Model as crucial in the delivery of trauma-informed care; however so far it has not been extensively researched by the IBMS social work academia and therapeutic social workers. ${ }^{38}$

Trauma-informed care in the social work does not address past trauma, as it is in the case of trauma - focused therapy, but it explores traumatized clients' problems in the light of their traumatic experiences. ${ }^{39}$ This type of care seeks to create a safe environment for clients, a sense of mutual respect and tolerance as well to establish a strong partnership between client and trauma-informed care social work provider. At present, there are tools avail-

\footnotetext{
${ }^{36}$ M. DAS, "Ecological Integrative Body-Mind-Spirit Approaches Within Conflict - Induced Displacement," in M.Y. LeE, C.H.Y. Chan, C.L.W. Chan, S.M. NG, P.P.Y. Leung, Integrative Body-Mind-Spirit Social Work An Empirically Based Approach to Assessment and Treatment (Oxford-New York, 2018), 270-279.

${ }^{37}$ Ibidem.

${ }^{38}$ Ibidem, 273.

${ }^{39}$ S.M. Brown, C.N. BaKer, P. Wilcox, "Risking Connection Trauma Training, A Pathway Toward Trauma-Informed Care in Child Congregate Care Settings," Psychological Trauma: Theory, Research, Practice (2012), 4, 5: 507-515.
} 
able to measure trauma-informed care, its operational barriers and readiness for change. For example, trauma-informed care protocols are accessible with the scale called ARTIC - Attitudes Related to Trauma Informed Care, which comprise seven domains including causes' attributions for problematic client behavior and therefore later might help social workers to direct preferred ways of responding to client symptoms.

In addition, in some social work agencies the self-assessment tool might turn useful to measure trauma-informed care progress. Nevertheless, several critical barriers block the further progression of research, practice and policy linked with trauma-informed care at large. Despite the recognition of core principles for trauma-informed care such as psychopathology; integration of trauma theory into stress explanation; trustworthiness; cores values of safety, choice, empowerment; and collaboration, avoiding of comportments which are against trauma-informed care, in the current research and writing these core principles blend in with administrative commitment, hiring policies and among others - trauma screening procedures. As a result, foundation policies remain consistent; however, its operationalization differs considerably due to a serious lack of strong psychometrical instrument which could evaluate succinctly trauma-informed care. The study work to further elaborate the ARTIC is to fill this evaluation lack. So far, the ARTIC has been evaluated in the United States on 760 service providers, with six subscales and two supplemental subscales supportive of trauma-informed care practices and 133-item questionnaire. ${ }^{40}$ The therapeutic social work with family refugees has not been distinguished in the initial evaluation, either the H5 Model.

\section{CONCLUSION}

Currently, whereas the therapeutic social work community has at their disposal numerous ways for interviewing traumatized clients - particularly refugee families - still not many therapeutic social workers turn to psychometric instruments which would measure trauma effectively in manifold manners - medically/clinically and psycho-socially. At times, ad hoc or not well crafted approaches towards the traumatized client - particularly refugees - lead to a situation when a therapy fails to assess correctly and in em-

\footnotetext{
${ }^{40}$ C.N. Baker, S.M. Brown, P.D. Wilcox, S. Overstreet, P. Arora, "Development and Psychometric Evaluation of the Attitudes Related to Trauma-Informed Care (Arctic) Scale," School Mental Health (2016), 8, 1: 61-76.
} 
pathic and validating manner the condition of the traumatized. Moreover, traumatic activation in a traumatized refugee might re-occur once in social services a negative clinician's responses evokes a sense of failure, which in turn will reinforce inflexible coping and anxieties, and most importantly will dissuade the traumatized form seeking help and healing. ${ }^{41}$ This evidencebased fact, as well as building upon best practices in joint work of clinicians and therapeutic social workers in specific projects, should force and encourage at the same time clinicians and therapists, including therapeutic social workers to work closely together - from the office and voluntarily, and use each other's psychometric instruments, once they are test-and evidence- proved to evaluate progress in trauma recovery of traumatized refugee families.

The H5 Model, predominantly its scale, with its simplicity of use, in fact draws upon the therapeutic social work foundations and revokes its values. While it takes into account "safety," "choice," "empowerment" and "collaboration," it reinforces the elements of spirituality, respect and altruism which is recalled by IBMS social work and which should also be essential for a success of all types of the therapeutic social work on trauma related aspects concerning not only refugees and their families, but also all traumatized communities. Clearly, substantial further research work on both sides founders' of the H5 Model and trauma informed care social workers should be conducted to identify whether and to what extent the H5 Model is in fact used by social work practitioners, might be used and how it may become one of constant elements to turn to psychometrically in every day therapeutic social work practice with traumatized refugee and their families. In addition, the H5 model could be well posited not only as an instrument within trauma - informed care psychometric evaluations but might play a role in social worker's education, training, evaluation.

\section{BIBLIOGRAPHY}

Baker, C.N., Brown, S.M., Wilcox, P.D., Overstreet, S., Arora, P. "Development and Psychometric Evaluation of the Attitudes Related to Trauma-Informed Care (Arctic) Scale." School Mental Health (2016), 8, 1: 61-76.

Brandmeier, M., Kruse, J. "Trauma und Asyl in Flüchtchlingsrecht in Theorie and Praxis: 5 Jahre Refugee Law Clinic an der Justus-Liebig-Universität Giessen, In P. Tiedemann, J. GieseKing, Flüchtlingsrecht in Theorie und Praxis. Baden Baden, 2014.

\footnotetext{
${ }^{41}$ E. TEYBER, F. MCCLURE, Interpersonal processes in therapy, An Integrative Model (Belmont, 2011), 335-337.
} 
Brown, S.M., BAKER, C.N., Wilcox, P. "Risking Connection Trauma Training, A Pathway Toward Trauma-Informed Care in Child Congregate Care Settings." Psychological Trauma: Theory, Research, Practice (2012), 4, 5: 507-515.

Carlson, E.A., Sroufe, L.A. "Contribution of Attachment Theory to Developmental Psychopathology.” In D. CichHeTti, D.J. CoHEN (eds.), Developmental Psychopathology. Vol I. Theory and Methods, 581-617. Oxford, 2014.

Congress, E.P. “The Culturagram.” In A. RoBerTs, Social Work Desk Reference, 969-973. New York-Oxford, 2008.

Congress, E.P. “The Culturagram.” In K. CoRCORAn, A.R. RoberTs. Social Worker's Desk Reference. New York, 2015.

DAS, M. "Ecological Integrative Body-Mind-Spirit Approaches Within Conflict - Induced Displacement." In M.Y. LeE, C.H.Y. Chan, C.L.W. ChAN, S.M. NG, P.P.Y. LeUnG. Integrative Body-Mind-Spirit Social Work An Empirically Based Approach to Assessment and Treatment, 270-279. Oxford-New York, 2018.

Elliott, D.E., BJElajaC, P., FAllot, R.D, MaRkofF, L.S. "Trauma-Informed or trauma-denied. Principles and Implementation of Trauma Informed Services for Women." Journal of Community Psychology (2005), 33, 4: 461-477.

FAllot, R.D., HARRIS, M. "Creating Cultures of Trauma-Informed Care (CCTIC), A SelfAssessment and Planning Protocol." Community Connections, April 2009, 1-19.

Hilado, A., Lundy, M. Models for Practice with Refugees and Immigrants, Collaboration, Cultural Awareness and Integrative Theory. Los Angelos-London, 2018.

JACKSON, K. “Treating Trauma in American Refugees.” Social Work Today (2016), 16, 4: 10.

Jovev, M., JACKson, H.J. "Early Maladaptive Schemas in Personality Disordered Individuals." Journal of Personality Disorders (2004), 18, 5: 467-486.

LeVenson, J.S. “Trauma- Informed Social Work Practice.” Social Work (2017), 62, 2: 1-9.

Miller, W.R., Rollnick, S. "Ten Things that Motivational Interviewing is not." Behavioural and Cognitive Psychotherapy (2009), 37, 2: 129-140.

Miller, W.R., Yahne, C.E., Moyers, T.B., Martinez, J., Pirritano, M. “A randomized trial of methods to help clinicians learn motivational interviewing." Journal of Consulting and Clinical Psychology (2004), 72: 1050-1062.

Mollica, R.F. The new H5 model, Trauma and Recovery. Harvard, 2014.

Mollica, R.F., Brooks, D.R., Ekblad, S., McDonald L. "The H5 New Model of Refugee Trauma and Recovery." In J. Lindert, I. LeVAV (eds.). Violence and Mental Health, Its Manifold Faces, 341-378. New York-London, 2015.

Mollica, R.F., Bollini, P., CAsPi, Y., Truong, T. "Harvard Trauma Questionnaire; Validating a Cross-Cultural Instrument for Measuring torture, Trauma, and Posttraumatic Stress Disorder in Refugees." Journal of Nervous \& Mental Disease (1994), 180, 2: 107-111.

Pathways to Wellness. Refugee Health Screener 15 (RHS 15). Washington, 2011.

Ротоску, M., Guskovict, K.L. "Enhancing Empathy among Humanitarian Workers through Project Miracle: Development and Initial Validation of the Helpful Responses to Refugee Questionnaire." Torture (2016), 26, 3: 46-59.

Schauer, M., Neuer, F., Elbert, T. Narrative Exposure Therapy: A Short Term Treatment for Traumatic Stress Disorders. Cambridge, 2002. 
SUDBURY, J. "Key features of therapeutic social work: The use of relationship." Journal of Social Work Practice (2002), 16, 2: 142-162.

TEYBER, E., MCCluRE, F. Interpersonal processes in therapy. An Integrative Model. Belmont, 2011. https://blog.oup.com/2016/09/un-summit-refugees-migrants-mi/.

http://hprt-cambridge.org/screening/harvard-trauma-questionnaire/.

https://doi.org/10.1093/eurpub/cky256 (3.03.2019).

https://doi.org/10.1080/13557858.2017.1379598.

https://healtorture.org/sites/healtorture.org/files/HTQ-R\%20and\%20HSCL-25\%20English\%20trans

lation\%20of\%20Cambodian\%20version\%20with\%20Torture\%20History.pdf.

https://www.unhcr.org/figures-at-a-glance.html.

\section{MODEL H5 DOTYCZĄCY TRAUMY UCHODŹCZEJ \\ ORAZ JEGO ZASTOSOWANIE W PRAKTYCE PRACY SPOŁECZNEJ \\ - CELEM ULEPSZENIA WSPARCIA RODZIN UCHODŹCZYCH. ROZWAŻANIA TEORETYCZNE I PRAKTYCZNE}

\section{STRESZCZENIE}

Autorzy dokonują analizy złożoności zagadnienia godności ludzkiej oraz godności ludzkiej jako koncepcji oraz jej umiejscowienia w ramach dzisiejszych form i praktyk pracy społecznej. W związku z tym autorzy rozważają tematykę pojmowania godności ludzkiej, w tym godności ludzkiej jako wartości społeczno-prawnej, jej istotności dla pracy społecznej w ogóle oraz z racji podstawowych wartości relewantnych dla pracy społecznej. Autorzy egzaminują ewolucję podejść pracy społecznej wobec godności ludzkiej koncentrując się na działalności organizacji międzynarodowych, ich członków stowarzyszonych i partnerów związanych z pracą społeczną, których zadaniem m.in. jest promować oraz dbać o przestrzeganie wartości godności ludzkiej w dostarczaniu codziennych praktyk i usług pracy społecznej.

Słowa kluczowe: opieka informacji traumy; uchodźca; rodzina uchodźcza; praca społeczna; praktyka pracy społecznej; terapeutyczna praca społeczna. 